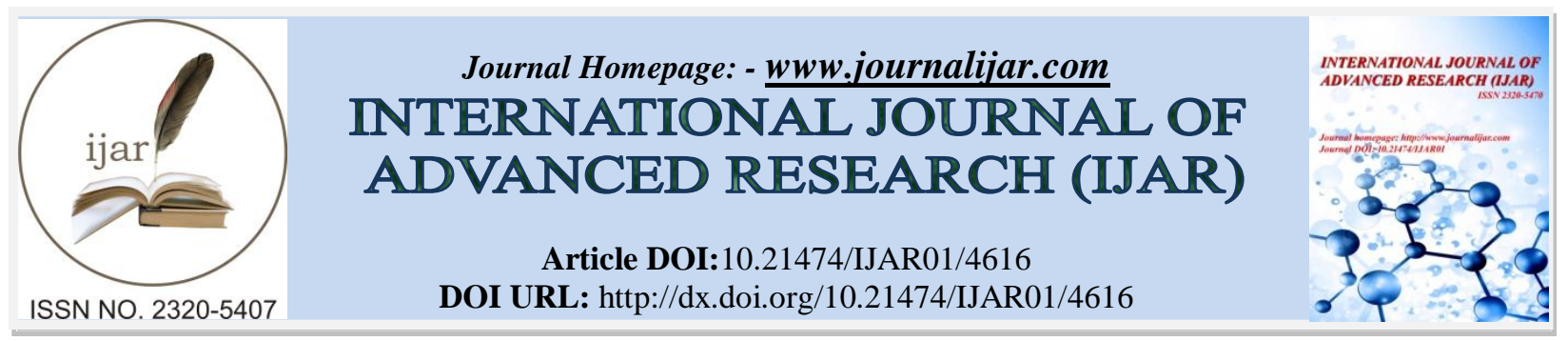

RESEARCH ARTICLE

\title{
STUDY ON EFFECT OF MONOVALENT AND DIVALENT SALTS ON THE PRODUCTION OF BIOSURFACTANT AND EMULSIFICATION INDEX.
}

\author{
C.C. Okore ${ }^{1 *}$, L.U. Nwaehiri ${ }^{1}$, O.N. Mbanefo ${ }^{1}$, T.E. Ogbulie ${ }^{2}$, A.U. Ugenyi ${ }^{2}$, I.B. Ogbuka ${ }^{1}$, A.E. Ejele ${ }^{3}$ and \\ I.A.Okwujiako ${ }^{2}$. \\ 1. Environmental Biology Dept, Federal Polytechnic Nekede Owerri, Imo-State. \\ 2. Biotechnology Dept, Federal University of Technology Owerri, Imo-State. \\ 3. Chemistry Dept, Federal University of Technology Owerri, Imo-State.
}

\section{Manuscript Info}

\section{Manuscript History}

Received: 25 April 2017

Final Accepted: 27 May 2017

Published: June 2017

Key words:-

Biosurfactant production, emulsification index, monovalent salt, divalent salt

\section{Abstract}

Biosurfactants are produced by micro organisms and are used in industrial and environmental applications as a result of their resistivity to harsh conditions. Their production can be affected by extreme environmental conditions like $\mathrm{pH}$, salinity, temperature, aeration. In view of this we studied the effect of monovalent salt $(\mathrm{KCl})$ and divalent salt $\left(\mathrm{MgCl}_{2}\right)$ on the biosurfactant producing activity and emulsification index of five bacterial strains (Staphylococcus aureus, Bacillus sp., Corynebacterium sp., Pseudomonas aeruginosa and Proteus sp.). The $\mathrm{KCl}$ and $\mathrm{MgCl}_{2}$ increased the biosurfactant production of all bacterial strains. The $\mathrm{KCl}$ affected emulsification index (E24) of all the strains except Proteus sp. that recorded the highest E24 of $41.6 \%$ with addition of $0.4 \mathrm{~g} \mathrm{KCl}$. The $\mathrm{MgCl}_{2}$ increased the E24 of Bacillus sp. (52.4\%; $0.1 \mathrm{~g})$; Corynebacterium sp. $(50 \% ; 0.1 \mathrm{~g})$; Pseudomonas aeruginosa $(56 \% ; 0.2 \mathrm{~g})$; Proteus sp. $(57.7 \% ; 0.4 \mathrm{~g})$. These bacterial isolates can be used in industries and environmental applications as a result of their tolerance to salt.

Copy Right, IJAR, 2017,. All rights reserved.

\section{Introduction:-}

Surface active agents which are produced by different groups of micro organisms are known as biosurfactant. Biosurfactants are environmentally friendly, biodegradable, less toxic and non harzardous. They have better foaming properties and higher selectivity. Biosurfactants are active at extreme temperatures, $\mathrm{pH}$, salinity and can be produced from industrial waste and by-products (Kosaric, 2001). This is important for industrial and biotechnological applications. Biosurfactants are very stable and effective in the culture medium that is used for their synthesis (Pacwa-Płociniczak et al., 2011). The industrial needs for biosurfactants are constantly increasing. Biosurfactants are widely used in different industries, such as cosmetics, food and beverages, pharmaceuticals, agriculture, cleaners, and in petroleum industry. In the petroleum industries, biosurfactants are used, in bioremediation of hydrocarbon polluted soils and waters, in microbial enhanced oil recovery, to reduce the heavy oil viscosity, clean up oil storage tanks, increase flow through pipelines and stabilize fuel water emulsion (Sharma and Pant, 2000, Makkar and Cameotra, 1997). During in situ application, bacteria for microbially enhanced oil recovery (MEOR) must be able to grow under extreme condition encountered in oil reservoir such as high temperature, pressure, salinity and low oxygen level. Emulsification of the hydrocarbons in water is a prerequisite that paves the way for biodegradation of environmental pollutants by many bacteria. The efficiency of biologically enhanced oil recovery 
has been proven in field studies in the United States, Czech Republic, Romania, Hungary, Poland and Holland with significant increases in oil recovery observed in all cases (Karanth et al., 1999). The industrial and environmental applications of the biosurfactant depend on their stability at extreme conditions of temperature, salinity, and $\mathrm{pH}$ (Joshi et al., 2008). Biosurfactant production rate by bacteria, like any other chemical reaction is affected by a number of factors which either increase or decrease its productivity rate, such include $\mathrm{pH}$, salinity and temperature (Joshi et al., 2008, Maneerat et al., 2005). Desai and Banat, (1997), ABU-Ruwaida et al., (1991) also affirm the fact that environmental factors and growth condition such as $\mathrm{pH}$, temperature, agitation, salinity, oxygen availability, affect cellular activity. Therefore the search for biosurfactant producing bacteria that can withstand harsh environmental conditions and rigorous industrial processes without affecting them led to this study on effects of monovalent and divalent salts $\left(\mathrm{KCl}_{\text {and }} \mathrm{MgCl}_{2}\right)$ on the production of biosurfactants and emulsification index.

\section{Methodology:- \\ Production of biosurfactants:-}

The test tubes were washed with hypo and detergent, peptone water and test tubes were sterilized in the auto clave for 15 minutes. Test tubes were labelled according to the isolates. In this study five (5) bacteria genera (Bacillus sp., Corynebacterium sp. Proteus sp., Pseudomonas aeruginosa and Staphylococcus aureus) positive for biosurfactant production were used. A loopful of each of the bacterium culture in agar slants was picked and inoculated into five different test tubes containing $4.5 \mathrm{ml}$ of peptone water and allowed to stand for $24 \mathrm{~h}$ at $37^{\circ} \mathrm{C}$. At the end of the incubation, different salt quantity $(0.0 \mathrm{~g}$ control, $0.1 \mathrm{~g}, 0.2 \mathrm{~g}, 0.3 \mathrm{~g}, 0.4 \mathrm{~g}$ and $0.5 \mathrm{~g})$ was added to each of the broth culture and incubated for 7 days. At the end of the incubation, each of the broth culture of test organisms containing the salt solutions were screened for biosurfactant production using emulsification index method to determine the various effects or degrees to which the test organisms produce biosurfactants. Also, the biosurfactants produced by each of the test organisms was extracted and compared with the control samples $(0.0 \mathrm{~g})$ without salt. The result obtained in this study is recorded and represents the effects of salts on biosurfactant production of the test organism.

\section{Emulsification index:-}

The emulsification capacity of the biosurfactant on kerosene $2 \mathrm{ml}$ was studied using $2 \mathrm{ml}$ of the cell free supernatant obtained after vortexing the 7 days sample culture at high speed for $2 \mathrm{~min}$ and allowed to stand for $24 \mathrm{~h}$. The emulsification index (E24) was calculated as the percentage of height of the emulsified layer (mm) divided by the total height of the liquid/aqueous column (mm) (Maneerat, 2005, Okore et al., 2013, Okore et al., 2017).

\section{Extraction of Biosurfactant:-}

The extraction was performed by acid precipitation followed by liquid-liquid extractions. After 7 days of incubation sterile Petri plates were taken and the weight of the plate measured before and after. The cell free supernatant or crude biosurfactant $(1 \mathrm{ml})$, got after centrifugation at 5,000 rpm for $15 \mathrm{~min}$, was poured on the plates and acidified with equal volume of acid $\left(1 \mathrm{ml}, 2 \mathrm{M} \mathrm{H}_{2} \mathrm{SO}_{4}\right)$ to attain a $\mathrm{pH}$ of 2.0 and extracted with an equal volume of solvent, chloroform: methanol (2:1). The resultant aliquot was shaken well for mixing and placed on the hot air oven for drying at $100^{\circ} \mathrm{C}$ for $30 \mathrm{~min}$. The white coloured sediment obtained was the crude biosurfactant and weighed (Morikawa et al., 2000). The dry weight of the biosurfactants was calculated by the following formula:

\section{Dry weight of biosurfactant $=$ Weight of the plates after drying-weight of the empty plates.}

\section{Result:-}

The result of the weight of biosurfactant produced by the different bacteria strains enhanced with different quantities of potassium chloride is presented in Table 1 . Table 2 is the result for the emulsification index produced by the different bacteria strains enhanced with different quantities of potassium chloride. Table 3 is the result for the weight of biosurfactant produced by the different bacteria strain enhanced with different quantities of magnesium chloride while Table 4 is the result for the emulsification index produced by the different bacteria strain enhanced with different quantities of magnesium chloride. 
Table 1:- Effect of potassium chloride salt on biosurfactant production.

\begin{tabular}{|c|c|c|c|c|}
\hline Isolate & $\begin{array}{l}\text { Weight of Petri dish } \\
\text { before extraction (g) }\end{array}$ & $\begin{array}{l}\text { Weight of Petri dish } \\
\text { after extraction (g) }\end{array}$ & $\begin{array}{l}\text { Weight of } \\
\text { biosurfactant (g) }\end{array}$ & $\begin{array}{l}\text { Quantity of } \mathrm{KCl} \text { in } \\
\text { bacterial suspension(g) }\end{array}$ \\
\hline \multirow{6}{*}{$\begin{array}{c}\text { Staphylococcus } \\
\text { aureus }\end{array}$} & 46.7 & 47.2 & 0.5 & 0.1 \\
\hline & 35.7 & 36.7 & 1.0 & 0.2 \\
\hline & 42.0 & 42.3 & 0.3 & 0.3 \\
\hline & 36.7 & 36.9 & 0.2 & 0.4 \\
\hline & 36.0 & 36.5 & 0.5 & 0.5 \\
\hline & 38.0 & 38.3 & 0.3 & 0 \\
\hline \multirow[t]{6}{*}{ Bacillus sp. } & 32.3 & 33.0 & 0.7 & 0.1 \\
\hline & 33.5 & 34.0 & 0.5 & 0.2 \\
\hline & 38.0 & 38.5 & 0.5 & 0.3 \\
\hline & 45.5 & 46.0 & 0.5 & 0.4 \\
\hline & 40.5 & 40.7 & 0.2 & 0.5 \\
\hline & 43.2 & 43.3 & 0.1 & 0 \\
\hline \multirow{6}{*}{$\begin{array}{c}\text { Corynebacterium } \\
\text { sp. }\end{array}$} & 40.1 & 40.7 & 0.6 & 0.1 \\
\hline & 41.8 & 42.3 & 0.5 & 0.2 \\
\hline & 43.0 & 44.5 & 1.5 & 0.3 \\
\hline & 46.2 & 46.5 & 0.3 & 0.4 \\
\hline & 35.5 & 36.7 & 1.2 & 0.5 \\
\hline & 42.0 & 42.2 & 0.2 & 0 \\
\hline \multirow{6}{*}{$\begin{array}{c}\text { Pseudomonas } \\
\text { aeruginosa }\end{array}$} & 35.0 & 35.3 & 0.3 & 0.1 \\
\hline & 31.9 & 32.9 & 1.0 & 0.2 \\
\hline & 30.3 & 30.7 & 0.4 & 0.3 \\
\hline & 36.0 & 36.3 & 0.3 & 0.4 \\
\hline & 36.8 & 37.0 & 0.2 & 0.5 \\
\hline & 32.0 & 32.1 & 0.1 & 0 \\
\hline \multirow[t]{6}{*}{ Proteus sp. } & 35.0 & 37.5 & 2.5 & 0.1 \\
\hline & 43.5 & 43.6 & 0.1 & 0.2 \\
\hline & 34.3 & 34.5 & 0.2 & 0.3 \\
\hline & 35.9 & 36.2 & 0.3 & 0.4 \\
\hline & 31.5 & 31.7 & 0.2 & 0.5 \\
\hline & 43.3 & 43.4 & 0.1 & 0 \\
\hline
\end{tabular}

Table 2:- Effect of potassium chloride salt on Emulsification index.

\begin{tabular}{|c|l|l|}
\hline \multirow{2}{*}{ Isolate } & \multicolumn{1}{c|}{$\begin{array}{c}\text { Quantity of KCl } \\
\text { in bacterial suspension }(\mathbf{g})\end{array}$} & Emulsification index E24(\%) \\
\hline \multirow{3}{*}{ Staphylococcus aureus } & 0 & 50.0 \\
\cline { 2 - 3 } & 0.1 & 9.0 \\
\cline { 2 - 3 } & 0.2 & 4.5 \\
\cline { 2 - 3 } & 0.3 & 10.0 \\
\cline { 2 - 3 } & 0.4 & 9.0 \\
\cline { 2 - 3 } & 0.5 & 13.0 \\
\hline \multirow{3}{*}{ Bacillus sp. } & 0 & 68.0 \\
\cline { 2 - 3 } & 0.1 & 10.5 \\
\cline { 2 - 3 } & 0.2 & 6.8 \\
\cline { 2 - 3 } & 0.3 & 9.5 \\
\cline { 2 - 3 } & 0.4 & 22.7 \\
\cline { 2 - 3 } & 0.5 & 6.6 \\
\hline \multirow{3}{*}{ Corynebacterium sp. } & 0 & 25.9 \\
\cline { 2 - 3 } & 0.1 & 7.6 \\
\cline { 2 - 3 } & 0.2 & 4.0 \\
\cline { 2 - 3 } & 0.3 & 4.0 \\
\cline { 2 - 3 } & 0.4 & 3.3 \\
\hline
\end{tabular}




\begin{tabular}{|c|l|l|}
\hline & 0.5 & 10.0 \\
\hline \multirow{3}{*}{ Pseudomonas aeruginosa } & 0 & 4.0 \\
\cline { 2 - 3 } & 0.1 & 4.0 \\
\cline { 2 - 3 } & 0.2 & 4.0 \\
\cline { 2 - 3 } & 0.3 & 4.7 \\
\cline { 2 - 3 } & 0.4 & 3.3 \\
\cline { 2 - 3 } & 0.5 & 16.6 \\
\hline Proteus sp. & 0 & 10 \\
\cline { 2 - 3 } & 0.1 & 25.0 \\
\cline { 2 - 3 } & 0.2 & 28.0 \\
\cline { 2 - 3 } & 0.3 & 21.4 \\
\cline { 2 - 3 } & 0.4 & 41.6 \\
\cline { 2 - 3 } & 0.5 & 17.2 \\
\hline
\end{tabular}

Table 3:- Effect of magnesium chloride salt on biosurfactant production.

\begin{tabular}{|c|c|c|c|c|}
\hline Isolate & $\begin{array}{l}\text { Weight of Petri dish } \\
\text { before extraction }\end{array}$ & $\begin{array}{l}\text { Weight of Petri dish } \\
\text { after extraction }\end{array}$ & $\begin{array}{c}\text { Weight of } \\
\text { biosurfactant }\end{array}$ & $\begin{array}{c}\text { Quantity of } \mathrm{MgCl}_{2} \\
\text { in bacterial } \\
\text { suspension }(\mathrm{g})\end{array}$ \\
\hline \multirow{6}{*}{$\begin{array}{l}\text { Staphylococcus } \\
\text { aureus }\end{array}$} & 35.5 & 36.6 & 1.1 & 0.1 \\
\hline & 24.0 & 24.2 & 0.2 & 0.2 \\
\hline & 24.3 & 25.2 & 0.9 & 0.3 \\
\hline & 34.7 & 35.3 & 0.6 & 0.4 \\
\hline & 39.5 & 41.5 & 2.0 & 0.5 \\
\hline & 24.8 & 25.2 & 0.4 & 0 \\
\hline \multirow[t]{6}{*}{ Bacillus sp. } & 32.8 & 33.0 & 0.2 & 0.1 \\
\hline & 51.0 & 51.3 & 0.3 & 0.2 \\
\hline & 32.0 & 32.5 & 0.5 & 0.3 \\
\hline & 30.65 & 31.5 & 0.85 & 0.4 \\
\hline & 20.60 & 22.2 & 1.6 & 0.5 \\
\hline & 20.0 & 20.8 & 0.8 & 0 \\
\hline \multirow[t]{6}{*}{ Corynebacterium sp. } & 20.0 & 20.5 & 0.5 & 0.1 \\
\hline & 20.0 & 20.4 & 0.4 & 0.2 \\
\hline & 20.0 & 20.3 & 0.3 & 0.3 \\
\hline & 40.9 & 41.3 & 0.4 & 0.4 \\
\hline & 43.0 & 43.8 & 0.8 & 0.5 \\
\hline & 42.1 & 42.5 & 0.4 & 0 \\
\hline \multirow{6}{*}{$\begin{array}{c}\text { Pseudomonas } \\
\text { aeruginosa }\end{array}$} & 33.0 & 33.4 & 0.4 & 0.1 \\
\hline & 31.8 & 32.2 & 0.4 & 0.2 \\
\hline & 28.5 & 28.8 & 0.3 & 0.3 \\
\hline & 33.0 & 33.5 & 0.5 & 0.4 \\
\hline & 50.0 & 50.3 & 0.3 & 0.5 \\
\hline & 31.5 & 31.8 & 0.3 & 0 \\
\hline \multirow[t]{6}{*}{ Proteus sp. } & 35.3 & 36.0 & 0.7 & 0.1 \\
\hline & 51.0 & 51.5 & 0.5 & 0.2 \\
\hline & 51.0 & 51.5 & 0.5 & 0.3 \\
\hline & 40.0 & 40.3 & 0.3 & 0.4 \\
\hline & 27.5 & 27.3 & 0.2 & 0.5 \\
\hline & 31.5 & 31.9 & 0.4 & 0 \\
\hline
\end{tabular}

Table 4:- Effect of magnesium chloride salt on Emulsification index.

\begin{tabular}{|c|c|c|}
\hline \multirow{2}{*}{ Isolate } & $\begin{array}{c}\text { Quantity of } \mathbf{M g C l}_{\mathbf{2}} \\
\text { in bacterial suspension }(\mathbf{g})\end{array}$ & $\begin{array}{c}\text { Emulsification index } \\
\text { E24 (\%) }\end{array}$ \\
\hline \multirow{2}{*}{ Staphylococcus aureus } & 0 & 12 \\
\cline { 2 - 3 } & 0.1 & 3.8 \\
\hline
\end{tabular}




\begin{tabular}{|c|c|c|}
\hline & 0.2 & 6.25 \\
\hline & 0.3 & 3.7 \\
\hline & 0.4 & 3.3 \\
\hline & 0.5 & 4 \\
\hline \multirow[t]{6}{*}{ Bacillus sp. } & 0 & 45 \\
\hline & 0.1 & 52.4 \\
\hline & 0.2 & 47.6 \\
\hline & 0.3 & 25 \\
\hline & 0.4 & 10 \\
\hline & 0.5 & 10 \\
\hline \multirow[t]{6}{*}{ Corynebacterium sp. } & 0 & 12 \\
\hline & 0.1 & 50 \\
\hline & 0.2 & 40 \\
\hline & 0.3 & 10 \\
\hline & 0.4 & 8 \\
\hline & 0.5 & 44.4 \\
\hline \multirow[t]{6}{*}{ Pseudomonas aeruginosa } & 0 & 33 \\
\hline & 0.1 & 7.1 \\
\hline & 0.2 & 56 \\
\hline & 0.3 & 4.3 \\
\hline & 0.4 & 4 \\
\hline & 0.5 & 4 \\
\hline \multirow[t]{6}{*}{ Proteus sp. } & 0 & 10.3 \\
\hline & 0.1 & 44 \\
\hline & 0.2 & 44 \\
\hline & 0.3 & 37.9 \\
\hline & 0.4 & 57.7 \\
\hline & 0.5 & 34.4 \\
\hline
\end{tabular}

\section{Discussion:-}

In this study the quantity of biosurfactant production increased with the addition of both monovalent salt $\mathrm{KCl}$ and divalent salt $\mathrm{MgCl}_{2}$ (Table 1 and Table 3). The quantity of biosurfactant produced by Staphylococcus aureus (Table 1) was highest $1.0 \mathrm{~g}$ with the addition of $0.2 \mathrm{~g} \mathrm{KCl}$ to the broth medium; $0.2 \mathrm{~g}$ biosurfactant was produced with the addition of $0.5 \mathrm{~g} \mathrm{MgCl}_{2}$ (Table 3). The highest quantity of biosurfactant produced by Bacillus sp., is $0.7 \mathrm{~g}$ (Table 1) when $0.1 \mathrm{~g} \mathrm{KCl}$ was used; also $1.6 \mathrm{~g}$ was produced with the addition of $0.5 \mathrm{~g} \mathrm{MgCl}_{2}$ (Table 3). Corynebacterium sp. produced the highest quantity of biosurfactant $1.5 \mathrm{~g}$ (Table 1) when $0.3 \mathrm{~g} \mathrm{KCl}$ was added to the medium; and $0.8 \mathrm{~g}$ produced with the addition of $0.5 \mathrm{~g} \mathrm{MgCl}_{2}$ to the medium (Table 3). The biosurfactant produced by Pseudomonas aeruginosa was highest $1.0 \mathrm{~g}$ (Table 1) with the addition of $0.2 \mathrm{~g} \mathrm{KCl}$; and $0.5 \mathrm{~g}$ produced when $0.4 \mathrm{~g} \mathrm{MgCl}_{2}$ was added to the medium (Table 3 ). Proteus sp. produced its highest quantity of biosurfactant $2.5 \mathrm{~g}$ (Table 1) with the addition of $0.1 \mathrm{~g} \mathrm{KCl}$ and $0.7 \mathrm{~g}$ biosurfactant produced with the addition of $0.1 \mathrm{~g} \mathrm{MgCl}_{2}$.

The result on Table 2 showed that the monovalent salt $\mathrm{KCl}$ affected the E24 recorded by the Staphylococcus aureus. The bacterial suspension with salt $0 \mathrm{~g}$ recorded the highest E24 (50\%). This value dropped as the quantity of $\mathrm{KCl}$ increased. The salt $\mathrm{KCl}$ also affected the E24 shown recorded by Bacillus sp. (Table 2). The control $0 \mathrm{~g}$ recorded the highest value for E24 as $68 \%$ and increased quantities dropped this value. The E24 recorded by Corynebacterium sp. with the $0 \mathrm{~g}$ of $\mathrm{KCl}$ was $25.9 \%$. This value dropped with the addition of $\mathrm{KCl}$ which has a negative effect on the E24 (Table 2). The bacteria Pseudomonas aeruginosa (Table 2) produced a highest E24 of $16 \%$ with the addition of 0.5 $\mathrm{g}$ of $\mathrm{KCl}$. The salt is needed by the organism for growth and breakdown of hydrocarbon. The Proteus sp. (Table 2) also recorded the highest E24 value with the addition of $0.4 \mathrm{~g}$ of $\mathrm{KCl}$ to $41.6 \%$. The salt $\mathrm{KCl}$ is tolerant to the Proteus sp. used in this study.

The effect of the divalent salt $\mathrm{MgCl}_{2}$ on emulsification index in the study recorded higher values with more of the bacteria studied than with the addition of the monovalent salt $\mathrm{KCl}$ to the bacterial broth medium. Bacillus sp. (Table 4) recorded $52.4 \%$ E24 with the addition of $0.1 \mathrm{~g}$ of the salt $\mathrm{MgCl}_{2}$ to the broth medium. This value decreased to 
$47.6 \%$ with the addition of $0.2 \mathrm{~g} \mathrm{MgCl}_{2}$. Corynebacterium sp. recorded a high E24 of 50\% (Table 4) with the addition of $0.1 \mathrm{~g} \mathrm{MgCl}_{2}$ and dropped to E24 of $44.4 \%$ with the addition of $0.5 \mathrm{~g} \mathrm{MgCl}_{2}$. Pseudomonas aeruginosa recorded (Table 4) E24 of $56 \%$ with the addition of $0.2 \mathrm{~g} \mathrm{MgCl}_{2}$ to the growth medium. Proteus sp. tolerated salt content (Table 4). The E24 value recorded with the addition of $0.4 \mathrm{~g} \mathrm{MgCl}_{2}$ is $57.7 \%$. The divalent salt was not tolerated by Staphylococcus aureus only (Table 4), the addition of $\mathrm{MgCl}_{2}$ affected negatively the E24. The E24 recorded without the addition of the $\mathrm{MgCl}_{2}$ is $12 \%$ but this value dropped to $3.3 \%$ with the addition of the salt.

This study showed that Pseudomonas aeruginosa and Proteus sp. tolerated the monovalent salt $\mathrm{KCl}$ (Table 2) added to the growth medium as this increased the E24 while Staphylococcus aureus, Bacillus sp. and Corynebacterium sp. were affected by the addition of the monovalent salt (Table 2). The study using divalent salt (Table 4$) \mathrm{MgCl}_{2}$ gave contrasting result to the monovalent salt $\mathrm{KCl}$ used. The Bacillus sp., Corynebacterium sp., Pseudomonas aeruginosa and Proteus sp. tolerated the $\mathrm{MgCl}_{2}$ recording high E24 values. Staphylococcus aureus (Table 4) was intolerant to the addition of $\mathrm{MgCl}_{2}$ in the culture medium.

Maneerat and Phetrong, (2007) studied the effect of monovalent salt $\mathrm{NaCl}$ and divalent salt $\mathrm{MgCl}_{2}$ on emulsification index of Bacillus sp. They found out that $\mathrm{MgCl}_{2}$ ranging from 0 to $0.1 \mathrm{M}$ had no effect on emulsifying index. The monovalent salt they used ranging from 0 to $9 \mathrm{M}$ had no effect on E24 but the higher molarity from $12 \mathrm{M}$ to $21 \mathrm{M}$ affected the E24 drastically as there was no E24 activity recorded. The result of this current study confirms this finding. Karanth et al., (1999) in their study found out that biosurfactant produced from Pseudomonas strains MEOR 171 and MEOR 172 were not affected by temperature, $\mathrm{pH}$, calcium, magnesium concentration in the ranges found in many oil reservoirs.

\section{Conclusion And Recommendation:-}

In conclusion only Staphylococcus aureus was intolerant to both $\mathrm{KCl}$ and $\mathrm{MgCl}_{2}$ used in the study (Table 2 and Table 4) while the other bacterial isolates can be used in the industries and environmental applications due to their tolerance to salt.

\section{Reference:-}

1. ABU-Ruwaida, A.S., Banat, M, Salem, S. and Kadri, A. (1991). Isolation of biosurfactant producing bacteria product characterization and evaluation. Acta. Biotechnol. 11(4):315-324

2. Bia, G., Brusseau, M.L. and Miller, R.M. (1998). Influence of cation type, ionic strength and $\mathrm{pH}$ on solubilization and mobilization of residual hydrocarbon by biosurfactant . J. of contam. hydrol 30:265-279.

3. Burd, G. and Ward, O.P. (1996). Physichochemical properities of PM-factor a surface active agent produced by Pseudomonas marginalis. Can. J. Micro biol. 42: 243-251.

4. Cameotra, S.S. and Makkar, R.S. (1998). Synthesis of biosurfactants in extreme conditions. Applied Microbiology and Biotechnology. 50: 520-529.

5. Desai, J.D. and Banat, I.M. (1997). Microbial production of surfactants and thedir commercial potential. Microbial. Mol. Bio Rev. 61: $41-64$.

6. Joshi, S., Bharucha, C., Jha, S., Yadav, S., Nerurkar, A. and Desai, A.J. (2008). Biosurfactant production using molasses and whey under thermophilic conditions. Bioresource Technology. 99:195-199.

7. Karanth, N.G.K., Deo, P.G. and Veenanadig, N.K. (1999). Microbial production of biosurfactants and their importance. Curr.Sci. 77:116-123.

8. Kosaric, N. (2001). Biosurfactants for soil bioremediation. Food Technology and Biotechnology. 39(4): 295304.

9. Makkar, R.S. and Cameotra S.S. (1997a). Utilization of molasses for biosurfactant production by two Bacillus strains at thermophilic conditions. J. Am. Oil Chem. Soc. 74:887-889.

10. Makkar, R.S. and Cameotra, S.S. (1997b). Biosurfactant production by a thermophilic Bacillus subtilis strain. J. Ind. MicrobialBiotechnol. 18:37-42.

11. Maneerat, S. (2005). Biosurfactants from marine organisms. Songklanakarin. J.Sci Technolo. 27(6):1265-1272

12. Maneerat, S. and Phetrong, K. (2007). Isolation of biosurfactant producing bacteria and characteristics of selected biosurfactant. Songklanakarin J. Sci. Technol. 29(3):781-791.

13. Morikawa, M., Hirata, Y. and Imanaka, T.A. (2000). Study on the structure, function and relationship of the lipopeptide biosurfactants. Biochem Biophys. Acta, 1488:211-218. 
14. Okore, C. C., Nwaehiri, L. U., Mbanefo, O.N., Ogbulie, T. E., Ugenyi, A. U., Ogbuka, I. B., Ejele A. E. and Okwujiako I. A. (2017). Study on microbial diversity of biosurfactant producing bacteria from contaminated enviromental samples. Int. J. Adv. Res. 5(6): 1387-1396, Doi:10.21474/IJAR01/4548, ISSN: 2320-5407.

15. Okore, C.C., Mbanefo, O.N., Onyekwere, B.C., Onyewenjo, S., Abba-Father, C.A.M. (2013). Isolation and Characterization of Biosurfactants Producing Bacteria from Oil Polluted Soil. Journal of Natural Sciences Research 3(5):119-122, www.iiste.org. ISSN 2224-3186 (Paper) ISSN 2225-0921 (Online).

16. Płociniczak, M.P., Płaza, G.A., Seget, Z.P. and Cameotra, S.S. (2011). Environmental applications of biosurfactants: Recent advances. Int. J. Mol. Sci., 12:633-654. Doi 10.3390/ijms 12010633.

17. Sharma, S.L. and Pant, A. (2000). Biodegradation and conversion of alkanes and crude oil by a marine Rodococcus. Biodegradation, 11(5):289-294 